\title{
ADDITIONAL RECORDS OF A NON-NATIVE FISH, THE SNOWY GROUPER, (Epinephelus niveatus) IN NOVA SCOTIAN WATERS
}

\author{
GLYN SHARP $^{1 *}$, JOHN GILHEN $^{2}$, MEGAN VEINOT $^{1}$ and \\ ROBERT SEMPLE ${ }^{1}$ \\ ${ }^{1}$ Population Ecology Division, Science Branch \\ Department of Fisheries and Oceans, Maritimes Region \\ Bedford Institute of Oceanography \\ PO Box 1006 \\ Dartmouth, Nova Scotia B2Y 4 A2 \\ ${ }^{2}$ Nova Scotia Museum of Natural History \\ 1747 Summer Street \\ Halifax, Nova Scotia B3H $3 A 6$
}

\begin{abstract}
At Clam Harbour, Nova Scotia in September 2005, two juvenile Snowy Groupers, Epinephelus niveatus (Valenciennes 1828), were captured. Subsequently, in October 2006 during the regular census of six artificial reefs in Sambro Harbour near Halifax, four juvenile Snowy Groupers were observed and one was captured. During the observation period the fish remained close to the reefs and fed voraciously. The arrival of the Snowy Groupers was correlated with the occurrence of a warm Gulf Stream tendril and their disappearance coincided with a drop in water temperature to $7.2^{\circ} \mathrm{C}$.
\end{abstract}

En septembre 2005, deux méroux neigeux juvéniles (Epinephelus niveatus - Valenciennes, 1828) ont été capturés à Clam Harbour (Nouvelle-Écosse). En octobre 2006, quatre méroux neigeux juvéniles ont été observés et un autre capturé durant l'inventaire régulier de six récifs artificiels dans le havre Sambro près de Halifax. Durant la période d'observation, les poissons sont demeurés près des récifs et se nourrissaient avec voracité. L'arrivée et le départ des méroux neigeux ont coïncidé avec l'arrivée et le départ d'une masse d'eau chaude amenée par le Gulf Stream (la température de l'eau a chuté jusqu'à $7,2^{\circ} \mathrm{C}$ une fois la masse d'eau chaude passée).

\section{INTRODUCTION}

Over the past 30 years 69 species from 33 families of non-indigenous fishes have been collected and recorded by the Nova Scotia Natural History Museum, Halifax, Nova Scotia (unpublished data). Both adult and juvenile stages appear in the near shore from July to September; the migrations peak in September.

One species, the Snowy Grouper, Epinephelus niveatus (Valenciennes 1828), is particularly noteworthy; it is a member of the family Serranidae (sea basses) (Robins et al. 1991) that consists of 35 genera with 370 species. The sea basses form "a large family of marine fishes, mostly demersal, occurring in tropical, subtropical and temperate seas; in shallow coastal waters and waters of moderate depths to $300 \mathrm{~m}$. Most are inhabitants of

\footnotetext{
* Author to whom correspondence should be addressed

E-mail address: sharpg@mar.dfo-mpo.gc.ca
} 
coral and rocky reefs". Individuals can live up to 25 years; their sizes are quite variable with lengths up to $3 \mathrm{~m}$ and weights up to $400 \mathrm{~kg}$. The fish are usually solitary and are mainly hermaphroditic. Four species: Yellowfin Bass, Anthias nicholsi (Gilhen \& McAllister 1981), Black Sea Bass, Centropristis striata, Red Barbier, Hemanthias vivanus and the Snowy Grouper, on occasion have strayed into Canadian Atlantic waters (Scott \& Scott 1988).

Two adult Snowy Groupers (measuring 76 and $104 \mathrm{~cm}$ ) were captured in 1978 and 1981 in deep (135-185 m) waters of the Scotian Shelf. However, the first record of Snowy Groupers in Atlantic waters is of two juveniles (3 $\mathrm{cm}$ ) caught in 1928 (Scott \& Scott 1988) within $10 \mathrm{~km}$ of the present-day observation location. Very little habitat information is available from these records. It is known that during the warmer months, the pelagic larvae can survive and grow outside their normal range if they find suitable habitat (Böhlke \& Chaplin 1970).

The normal range for $E$. niveatus runs from southeastern Brazil to Cape Hatteras, North Carolina (Moore \& Labisky 1984). Adults are found on the upper continental slope at depths of 240 to $484 \mathrm{~m}$ while juveniles inhabit shallower nearshore waters on rock, sand or mud bottoms as well as wrecks and reefs (Matheson \& Huntsman 1984, Coad et al. 1995). The juvenile specimens (6-40 cm standard length) are "dark brown with conspicuous white spots in about 11 vertical series and 5 longitudinal rows, usually extending onto head and dorsal fin; caudal and pectoral fins pale yellow with a black saddle blotch on caudal peduncle reaching below the lateral line" (Heemstra \& Randall 1993). Adults are distinguished by a coppery gold colour, 18 vertical dark bands on the sides with the rear margin of the caudal fin being straight or concave versus convex in juveniles (Heemstra \& Randall 1993).

The recent discovery of the Snowy Groupers occurred during regular biological monitoring of artificial reefs constructed to support faunal and floral abundance and diversity. These artificial reefs are constructed in Atlantic Canada in accordance with regulations under the Oceans Act to mitigate or compensate where marine habitat is damaged or lost through projects such as wharf infilling. In this case rock reefs were used to replace the loss of habitat in Sambro Harbour resulting from an infill to create a wharf.

\section{MATERIALS AND METHODS}

Between 14 and 25August 2006, three rock reef modules were constructed at each of two sites in Sambro Harbour: Cook Head and Inner Sambro Island, near Halifax (Fig 1). The underlying substrate was sand stabilized by Zostera marina (eelgrass) at Inner Sambro; at Cook Head the substrate was a sand and mud mixture. The reefs in $10 \mathrm{~m}$ of water consisted of 20 numbered rock piles $4 \mathrm{~m}$ apart in a 5 by 4 array. Each pile consisted of 270 $\mathrm{kg}$ of rocks, graded to a minimum dimension of $15 \mathrm{~cm}, 1.0-1.2 \mathrm{~m}$ diameter, $0.3 \mathrm{~m}$ high. The footprint of each array of rock piles was $460 \mathrm{~m}^{2}$, and 3 ar- 


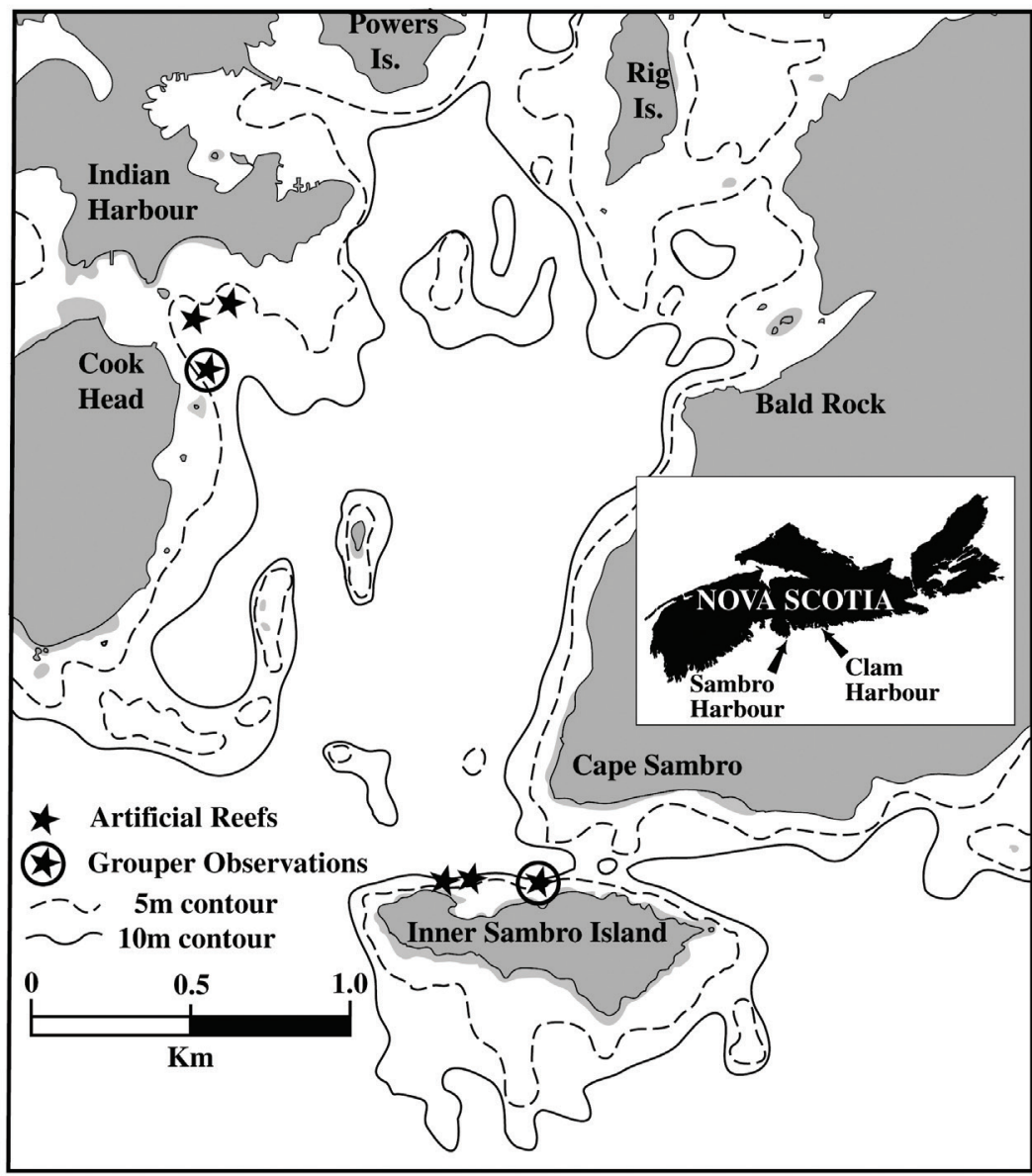

Fig 1. (Inset) Two locations in Nova Scotia where juvenile Snowy Groupers, Epinephelus niveatus, were captured in 2005 and 2006. (Large map) Locations of artificial reefs in Sambro Harbour and where Snowy Groupers were observed in 2006.

rays were placed at each site for a total reef area of $2760 \mathrm{~m}^{2}$. All reef units were in place by August 25, but further rearrangement and disturbance of the habitat continued until September 18.

Following deployment, a weekly inspection of all reefs began on September 25; a diving census of all macrofauna was conducted both in the piles and the surrounding substrate to $1 \mathrm{~m}$ beyond the outer boundary of the array. Species were identified in situ and no rocks were moved during the census. Bottom temperatures were recorded on each dive with digital thermometers; surface temperatures were available from the ocean data buoy C 44258 Halifax Harbour (MEDS 2006). 


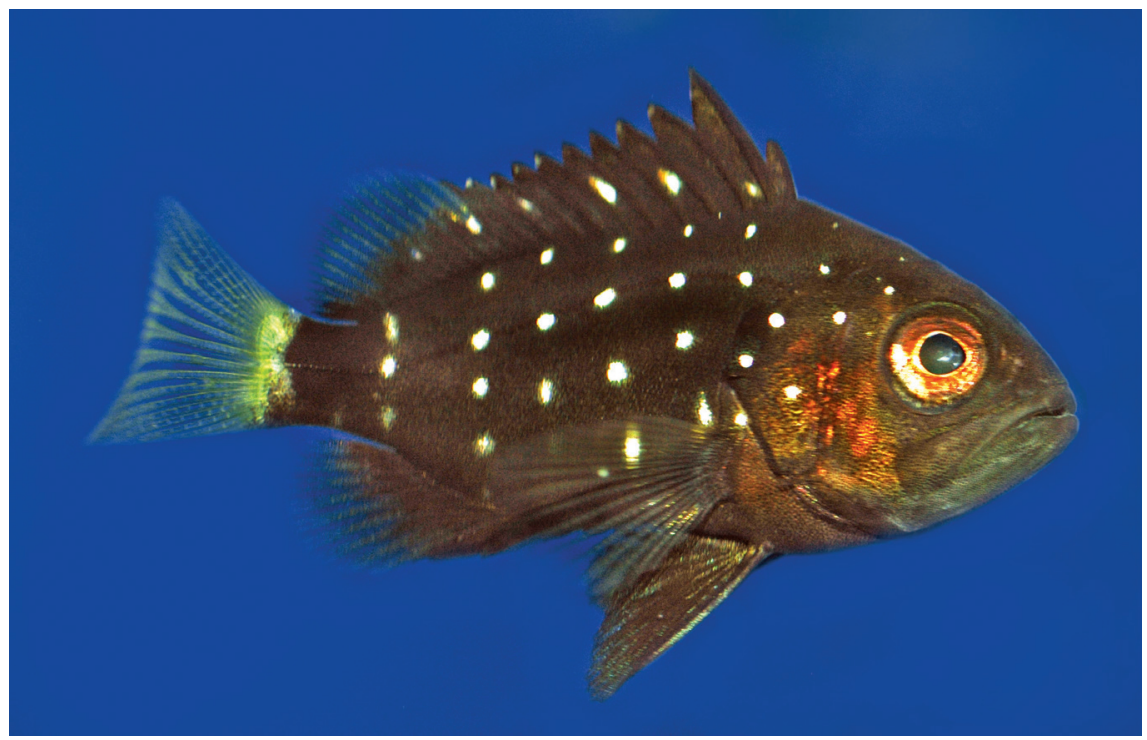

Fig 2. A juvenile Snowy Grouper, Epinephelus niveatus, captured on an artificial reef near Halifax, NS, Canada $2.5 \mathrm{~cm}$ total length

\section{RESULTS AND DISCUSSION}

The first Snowy Grouper detected was a $2.5 \mathrm{~cm}$ individual on October 3 in a reef at Inner Sambro (Fig 1B). The fish occupied the upper part of the rock pile and moved in and out staying within $10 \mathrm{~cm}$ of the opening. On October 20 three fish with similar characteristics and in the same size range were observed at the Cook Head reef module (Fig 1B). Two fish occupied one rock pile and the third was found $6 \mathrm{~m}$ away in a second rock pile. On October 24 these three fish were observed in the same numbered rock piles and one was captured alive for identification and measurement. Returning to the same sites November 1, no Snowy Groupers were found on either reef.

Snowy Groupers grow rapidly and at the end of the first year reach 20 $\mathrm{cm}$ (Matheson \& Huntsman 1984), thus these specimens that ranged in size from $2-3.5 \mathrm{~cm}$ were very early juveniles. Interestingly, these fish were observed making repeated feeding attacks on the abundant Mysis spp. (Opossum shrimp) around the rock piles. This is consistent with the known behaviour of Snowy Groupers which, because of their usual diet (pelagic fishes, crabs and squid), require the development of very aggressive feeding habits at an early age (Bielsa \& Labisky 1987, Coad et al. 1995, Colin et al. 1996).

The temperature on the reefs after their completion on September 25 was $18.1^{\circ} \mathrm{C}$, almost the summer maximum. On the first observation of $E$. niveatus (October 3 ) the temperature was $14.6^{\circ} \mathrm{C}$ and on the last observation 
(October 24) the temperature had dropped to $12.7^{\circ} \mathrm{C}$. The following week (November 1) the temperature had dropped to $7.2^{\circ} \mathrm{C}$. Not surprisingly, the fish could not be found on the artificial reef and it was presumed that their disappearance was related to this cooling as expatriates frequently die when the water cools significantly (McBride \& Able 1998).

Artificial reef habitat in Florida attracted settlement of juvenile $E$. niveatus $(2-10 \mathrm{~cm}$ ) as a preferred habitat to natural reefs (Arena et al. 2004). The artificial reefs in our study, however, were significantly different in structure from the reef balls and shipwrecks surveyed in Florida (Arena et al. 2004).

Following the observation in the field, one specimen was captured (24 October 2006), retained in an aquarium and identified as E. niveatus (Heemstra \& Randall 1993). On 19 September 2005, two juvenile Snowy Groupers were collected by snorkelers at Clam Harbour $60 \mathrm{~km}$ east of Halifax (and held in captivity overnight). The animals collected by snorkelers and those found in the artificial reef were dark bluish brown with distinctive white dots over the body. The caudal fin was bright yellow (Fig 2).

The morphometrics of the Clam Harbour specimens were:

NSM 88098: Weight (W) $1.78 \mathrm{~g} ; 47.0 \mathrm{~mm}$ in Total Length (TL); $36.4 \mathrm{~mm}$ Standard Length (S L); $23.2 \mathrm{~mm}$ Snout/Vent Length (S/V L); $15.7 \mathrm{~mm}$ Head Length (H L); 4.5mm Orbit Diameter (O D); $15.5 \mathrm{~mm}$ Pre Dorsal Length (PD L); $15.0 \mathrm{~mm}$ Pre Dorsal Depth (PD D); $7.0 \mathrm{~mm}$ Greatest Width (G W).

NSM 88099: W $2.06 \mathrm{~g} ; 46.7 \mathrm{~mm}$ TL; $36.5 \mathrm{~mm} \mathrm{~S} \mathrm{L;} 23.5 \mathrm{~mm} \mathrm{S/V} \mathrm{L;} 16.4$ $\mathrm{mm} \mathrm{H} \mathrm{L;} 4.3 \mathrm{~mm}$ O D; $15.4 \mathrm{~mm}$ PD L; $14.7 \mathrm{~mm}$ PD D; $7.0 \mathrm{~mm} \mathrm{G} \mathrm{W.}$

Dorsal Fin with $X$ spines, 13 rays; Anal Fin with II spines, 10 rays for both specimens.

Although it is not uncommon for the Scotian Shelf of Atlantic Canada to receive exotic species, collections are usually incidental to fishing and lack habitat data. Settlement in the same time frame in two separated reefs (1.9 $\mathrm{km}$ apart) suggests transport of a significant number of animals. Eggs of $E$. niveatus are pelagic and their larvae can be entrained by the Gulf Stream and transported north to offshore Atlantic Canada. This is a common route for larval fish transport from the southeast of the United States to the northeast continental shelf (Hare et al. 2002). Warm water meanders between the Gulf Stream and the continental shelf can be the transport mechanism for larval fish into the nearshore (Flierl \& Wroblewski 1984). The planktonic egg through larval phase of groupers (Serranidae) requires 30 to 40 days (Colin et al. 1996). If Snowy Grouper eggs were released into the centre of the Gulf Stream the larvae could cover the distance of $1500 \mathrm{~km}$ north in about 30 days (Clarke 2006) and the larvae would reach Nova Scotia just as they were completing metamorphosis and would be ready for settlement. On September 3 and on September 20, satellite images (NOAA- 18 Sea Surface Temperature: Sept 03, 20061708 GMT and NOAA-17 Sea Surface Temperature: Sept 20, 20060252 GMT) (IMCS, 2006) of surface water 
temperatures suggest there were meanders from the Gulf Stream that could provide the transport from the main stream to Sambro Harbour. Similarly in 2005 , there was a strong influx of warm water into Nova Scotian inshore waters from the Gulf Stream on August 30 to September 3 (NOAA-17 Sea Surface Temperature: Aug 30, 20050210 GMT and NOAA-12 Sea Surface Temperature: Sept 03, 20050936 GMT) (IMCS, 2006).

September is the optimal month for finding exotic fish species on the Atlantic coast of Nova Scotia. There is no clear evidence, however, for a greater number of arrivals in recent decades. Increasing use of the seashore and greater awareness among the general public of coastal ecology and more intense sub-tidal research may explain the more frequent observations.

Acknowledgements. We are grateful to Christina, Katherine and Margaret Nunn for donating both specimens from Clam Harbour to the Nova Scotia Museum of Natural History. We appreciate the advice provided by Oceanographers Gary Bugden and Allyn Clarke, Bedford Institute of Oceanography on dynamics of the Gulf Stream. Andrew Hebda, Nova Scotia Museum of Natural History, made helpful suggestions during preparation of the manuscript.

\section{REFERENCES}

Arena PT, Quinn TP, Jordan JKB, Sherman RL, Harttung FM, Spieler RE (2004) Presence of juvenile Blackfin Snapper, Lutjanus buccanella, and Snowy Grouper, Epinephelus niveatus, on shallow-water artificial reefs. Proc Gulf Caribb Fish Inst 55:690-712

Bielsa LM, Labisky RF (1987) Food habits of blueline tilefish, Caulolatilus microps, and snowy grouper, Epinephelus niveatus, from the lower Florida Keys. Northeast Gulf Sci 9(2):77-87

Böhlke JE, Chaplin CCG (1970) Fishes of the Bahamas and adjacent tropical waters. Academy of Natural Sciences of Philadelphia, Wynnewood, PA

Clarke RA (2006) (Bedford Institute of Oceanography, Dartmouth) Personal communication

Coad BW, Waszczuk H, Labignan I (1995) Encyclopedia of Canadian fishes. Canadian Museum of Nature \& Canadian Sportfishing Productions, Waterdown, ON

Colin PL, Koenig CC, Laroche WA (1996) Development from egg to juvenile of the red grouper (Epinephelus morio) (Pisces: Serranidae) in the laboratory. In: Arreguín-Sánchez F, Munro JL, Balgos MC, Pauly D (eds) Biology, fisheries and culture of tropical groupers and snappers. International Center for Living Aquatic Resources (ICLARM). Conf Proc No 48, p 399-414

Flierl, GR, Wroblewski JS (1985) The possible influence of warm core Gulf Stream rings upon the shelf water larval fish distribution. Fish Bull 83(3): 313-330

Gilhen J, McAllister DE (1981) First Canadian record of yellowfin bass, Anthias nicholsi Firth, taken off Nova Scotia. Proc NS Inst Sci 31:251-254

Hare JA, Churchill JH, Cowen RK, Berger TJ and 5 others (2002) Routes and rates of larval fish transport from the southeast to the northeast United States continental shelf. Limnol Oceanogr 47(6):1774-1789 
Heemstra PC, Randall JE (1993) Groupers of the world (Family Serranidae, Subfamily Epinephelinae). An annotated and illustrated catalogue of the grouper, rockcod, hind, coral grouper and lyretail species known to date. FAO Species Catalogue 16

IMCS (Institute of Marine and Coastal Sciences, Rutgers University, New Brunswick, NJ) (2006) IMCS Satellite Images. NOAA Sea Surface Temperatures. Available from <http://marine.rutgers.edu/cool> [accessed 13 December 2006]

Matheson RH III, Huntsman GR (1984) Growth, mortality, and yield-per-recruit models for Speckled Hind and Snowy Grouper from the United States South Atlantic Bight. Trans Am Fish Soc 113:607-616

McBride RS, Able KW (1998) Ecology and fate of butterfly fishes, Chaetodon spp., in the temperate, western North Atlantic. Bull Mar Sci 63:401-416

MEDS (Marine Environmental Data Service, Fisheries and Oceans Canada) (2006) Archive Plot. Available from <http://www.meds-sdmm.dfo-mpo.gc.ca/meds/ Databases/WAVE/ArchPlot/ArchPlot_Form_e.asp> [accessed 11 December 2006]

Moore CM, Labisky RF (1984) Population parameters of a relatively unexploited stock of Snowy Grouper in the Lower Florida Keys. Trans Am Fish Soc 113:322-329

Robins CR, Bond CE, Brooker JR, Lachner EA, Robert NL, Scott WB (1991) Common and scientific names of fishes from the United States and Canada. Am Fish Soc Special Publication 20

Scott WB, Scott MG (1988) Atlantic fishes of Canada. Can Bull Fish Aquat Sci 219:1-731 
